\title{
Bioavailability of biologically sequestered cadmium and the implications of metal detoxification
}

\author{
William G. Wallace ${ }^{1, *}$, Glenn R. Lopez ${ }^{2}$ \\ ${ }^{1}$ United States Geological Survey, MS 465, 345 Middlefield Road, Menlo Park, California 94025, USA \\ ${ }^{2}$ Marine Sciences Research Center, SUNY at Stony Brook, Stony Brook, New York 11794-5000, USA
}

\begin{abstract}
The deposit-feeding oligochaete Limnodrilus hoffmelsteri possesses metallothionein-like proteins and metal-rich granules for storing and detoxifying cadmium (Cd). In this study we investigated the bioavailability of $\mathrm{Cd}$ sequestered within this oligochaete by conducting feeding experiments with ${ }^{109} \mathrm{Cd}$-labeled oligochaetes and the omnivorous grass shrimp Palaemonetes pugio. We also make predictions on $\mathrm{Cd}$ trophic transfer based on oligochaete subcellular $\mathrm{Cd}$ distrubutions and absorption efficiencies of $\mathrm{Cd}$ by shrimp. Cytosol (including metallothionein-like proteins and other proteins) and a debris fraction (including metal-rich granules and tissue fragments) isolated from homogenized ${ }^{109} \mathrm{Cd}$ labeled oligochaetes were embedded in gelatin and fed to shrimp. The ${ }^{199} \mathrm{Cd}$ absorption efficiencies of shrimp fed these subcellular fractions were 84.8 and $48.6 \%$, respectively, and were significantly different $(p<0.001)$, indicating that ${ }^{109} \mathrm{Cd}$ bound in these fractions was not equally available to a predator. Mass balance equations demonstrate that shrimp fed whole worms absorb $61.5 \%$ of the ingested ${ }^{109} \mathrm{Cd}$. an absorption efficiency similar to that obtained experimentally $(57.1 \%)$. Furthermore, the majority of the absorbed ${ }^{109} \mathrm{Cd}$ comes from the fraction containing metallothionein-like proteins (i.e. cytosol). ${ }^{109} \mathrm{Cd}$ absorbed from the debris fraction probably comes from the digestion of tissue fragments, rather than metal-rich granules. The ecological significance of these findings is that prey detoxification mechanisms may mediate the bioreduction or bioaccumulation of toxic metals along food chains by altering metal bioavailability. Another important finding is that trophic transfer of metal can be predicted based on the subcellular metal distribution of prey.
\end{abstract}

KEY WORDS: Detoxification - Trophic transfer · Cadmium · Oligochaetes · Grass shrimp

\section{INTRODUCTION}

The first reported concern for anthropogenically induced elevated cadmium (Cd) concentrations was in the 1930s, and involved an endemic disease found in residents of the Jintsu River Basin in Japan (Yamagata 1973). The symptoms of Itai-Itai or Ouch-Ouch disease, so called because of the pain produced in the bone, were noted in 1935, and the connection between this condition and the consumption of Cd-contaminated rice was finally made in 1973 (Yamagata 1973). Cd is introduced into the environment from several sources; anthropogenic inputs from electroplating, manufactur-

\footnotetext{
·E-mail:wwallace@usgs.gov
}

ing of alloys, pigments, plastics and batteries are the most important (Brenner 1974, Nomizama 1980). Due to the release of municipal and industrial wastes into harbors and coastal bodies of water via outfalls and runoff from urban and agricultural areas, aquatic environments are particularly vulnerable to the impacts of metal pollutants such as $\mathrm{Cd}$. The transfer of $\mathrm{Cd}$ through aquatic food chains is of interest because $\mathrm{Cd}$ is considered to be one of the most toxic metals; the toxicity of $\mathrm{Cd}$ to aquatic invertebrates is well documented (Sprague 1986, Sadiq 1992).

Cd has a high affinity for sulfur and sulfur-containing functional groups [i.e. sulphydryl (-SH); disulphide (-S-S-); thioether $(-\mathrm{SR})]$, so it can interfere with the binding of essential metals ( $\mathrm{Zn}$ and $\mathrm{Cu}$ ) at reactive sites of enzymes (Nieboer \& Richardson 1980). Toxicity 
can also occur due to the displacement of $\mathrm{Ca}$ by $\mathrm{Cd}_{i}$ these metals have similar ionic radii (109 and $114 \mathrm{pm}$, respectively) (see Huheey 1983). Cd toxicity can be manifested at all levels of biological organization, including changes in enzyme activities, tissue damage, abnormal development and reduced growth, alterations in swimming and feeding behavior, and reduced fecundity (Capuzzo 1981, Sprague 1986). These toxicological effects can be countered by metal detoxification mechanisms involving the binding of metal to metal-binding proteins, such as metallothioneins (MT), and the precipitation of metal into metal-rich granules (MRG) (Roesijadi 1980, Brown 1982, Hamer 1986). MT and MT-like proteins play important roles in the regulation of essential metals like $\mathrm{Zn}$ and $\mathrm{Cu}$ and in the detoxification of toxic metals such as $\mathrm{Cd}$ and $\mathrm{Hg}$ (Kagi \& Vallee 1961, Cousins 1985, Hamer 1986, Kagi \& Kojima 1987). MRG are electron-dense concretions $(0.5$ to $>25 \mu \mathrm{m}$ ) of concentrated metal salts (Coombs \& George 1978). These granules function in the storage and excretion of essential and non-essential metals, and their production is common in all major phyla (Brown 1982, George 1982). The goal of our researrh was to determine how Cd detoxification by MT and MRG controls metal trophic transfer.

The bioavailability of metal is controlled by its chemical and physical form in water, sediment and food (Sunda et al. 1978, Bryan 1979, Luoma 1989). Detoxification mechanisms alter a metal's physical form and increase metal body burdens of prey (Bryan 1979, Roesijadi 1980, Klerks \& Levinton 1989a). These mechanisms may therefore play an important role in controlling metal trophic transfer. The importance of detoxification in controlling metal bioavailability is becoming apparent, but a complete understanding of how these detoxification mechanisms influence metal trophic transfer is lacking (Nott \& Nicolaidou 1989. 1990, Wallace \& Lopez 1996). The aim of this study was to identify the role of these detoxification mechanisms in controlling metal trophic transfer. This was accomplished by isolating subcellular fractions containing detoxified metal (i.e. MT and MRG) from metal exposed prey, feeding the fractions to a predator and then determining the predator's absorption of the ingested metal. Absorption data was then used to predict metal trophic transfer.

The prey chosen for this study was the depositfeeding oligochaete Limnodrilus hoffmeisteri. This oligochaete is the most abundant macrofaunal organism inhabiting the sediment of a heavily Cd contaminated cove, Foundry Cove, New York, USA, on the Hudson River (Klerks 1987). This cove was polluted with waste water from a $\mathrm{Ni}-\mathrm{Cd}$ battery plant and sediment $\mathrm{Cd}$ concentrations reached as high as $225000 \mu \mathrm{g} \mathrm{g}^{-1}$ dry wt, though most sediment had $\mathrm{Cd}$ concentrations on the order of $500 \mu \mathrm{g} \mathrm{g}^{-1}$ dry wt (Knutson et al. 1987). Cd bioaccumulation has been noted in Foundry Cove plants, blue crabs, killifish and frogs (Kneip \& Hazen 1979, Hazen \& Kneip 1980). L. hoffmeisteri in the cove attain substantial Cd body burdens, reaching as high as $1124 \mu \mathrm{g} \mathrm{g}^{-1}$ dry wt or higher in some cases (Klerks \& Levinton 1989b). These oligochaetes evolved resistance to $\mathrm{Cd}$ and this resistance is believed to be attributed to the binding of Cd to MT-like proteins and precipitation into MRG, probably CdS (Klerks \& Levinton 1989b, Klerks \& Bartholomew 1991). High Cd body burdens and Cd detoxification by MT-like proteins and MRG made $L$. hoffmeisteri an ideal organism to use in our studies investigating the trophic transfer of detoxified metal.

The predator used in this study was the grass shrimp Palaemonetes pugio. This shrimp is an important link between contaminated bottom sediments and higher trophic levels because it is an abundant benthic omnivore of marsh-cove ecosystems, it feeds on a variety of benthic invertebrates (including oligochaetes) and it is an integral part of coastal food chains (Nixon \& Oviatt 1973, Welsh 1975, Bcll \& Coull 1978, I Iofinan 1980j. P. pugio is abundant in Foundry Cove in late summer and early fall, and has been shown to exhibit manifestations of Cd toxicity, such as tissue damage, alterations in respiration and swimming behavior as well as reductions in prey capture (Nimmo et al. 1977. Hutcheson et al. 1985, Wallace 1996).

\section{METHODS}

General experimental protocol. Cd trophic transfer from oligochaetes to grass shrimp was investigated in 5 feeding experiments. Shrimp were fed either whole oligochaetes, homogenized oligochaetes mixed with gelatin or 1 of 3 oligochaete subcellular fractions (debris, intracellular or cytosol) mixed with gelatin (Fig. 1).

Radiolabeling of worms. During the summer of 1991 Limnodrilus hoffmeisteri, sediment $\left(9000 \mu \mathrm{g} \mathrm{Cd} \mathrm{g}^{-1} \mathrm{dry}\right.$ wt) and water $(0 \mathrm{ppt})$ were collected from Foundry Cove and maintained in a laboratory culture (20 to $23^{\circ} \mathrm{C}$ ) (Bonacina et al. 1989). Over the next few months 3 groups of worms ( 20 worms per group) were removed from the culture and, after voiding gut contents, individual worms were placed into glass vials containing $15 \mathrm{ml} 0.2 \mu \mathrm{m}$ filtered Hudson River water (0 ppt) containing trace amounts $\left(2.0,3.7\right.$ and $10.4 \mathrm{ng} \mathrm{Cd} \mathrm{l}^{-1}$ or 44,74 and $203 \mathrm{kBq} \mathrm{l}^{-1}$, respectively) of the gammaemitting radioisotope ${ }^{109} \mathrm{Cd}\left(t_{1 / 2}=462 \mathrm{~d}\right)$. These sets of worms were used in Expts 1,2 and 3-5, respectively. The background concentration of $\mathrm{Cd}$ in the Hudson River water was estimated to be on the order of $0.5 \mu \mathrm{g}$ 


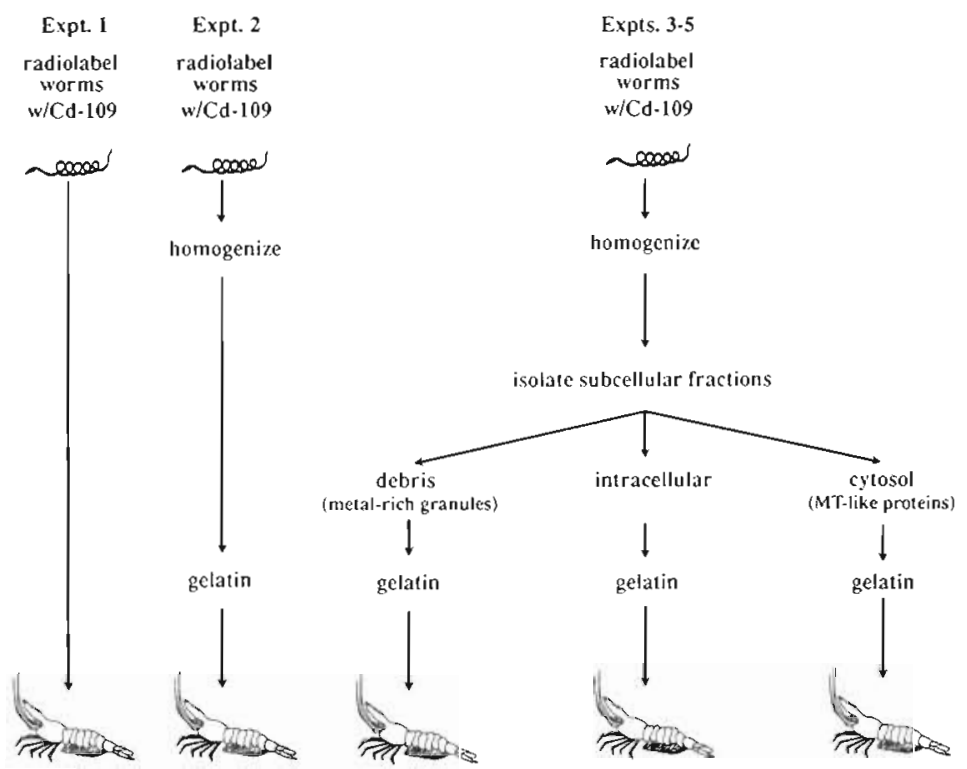

Fig. 1 Experimental protocol for conducting ${ }^{109} \mathrm{Cd}$ absorption experiments. Limnodrilus hoffmeisteri were radiolabeled with ${ }^{109} \mathrm{Cd}$ via solution, and Palaemonetes pugio were fed either whole worms (Expt 1), homogenized worms mixed with gelatin (Expt 2), or 1 of 3 worm subcellular fractions mixed with gelatin (Expts 3-5)

$\mathrm{I}^{-1}$ (Wallace \& Lopez 1996). After $6 \mathrm{~d}$, worms were removed from the vials, rinsed in distilled water and assayed for radioactivity. Samples were analyzed for ${ }^{109} \mathrm{Cd}$ in a Pharmacia-Wallac LKB automated gamma counter equipped with a Nal crystal. Samples were gamma counted for 5 min and counts were converted to $\mathrm{dpm} ;{ }^{109} \mathrm{Cd}$ standards were used to measure $70 \%$ counting efficiency.

Shrimp preparation. Experiments were conducted between October 1991 and January 1992. Because Palaemonetes pugio are abundant in Foundry Cove only in late summer and early fall, shrimp for these experiments were collected from a salt marsh on the north shore of Long Island, New York, USA. Grass shrimp were held in an aquarium $\left(20\right.$ to $\left.23^{\circ} \mathrm{C}\right)$, and over a $2 \mathrm{wk}$ period were acclimated from a field salinity of $-25 \mathrm{ppt}$ to the experimental salinity of $5 \mathrm{ppt}$. A salinity of 5 ppt was chosen because it is the highest observed in Foundry Cove and it is not stressful to shrimp (Wood 1967). Shrimp were fed Tetramin ${ }^{\otimes}$ fish food daily, but $2 \mathrm{~d}$ prior to the feeding experiments food was withheld.

Feeding experiment with whole worms (Expt 1). To determine ${ }^{109} \mathrm{Cd}$ bioavailability in oligochaetes, shrimp were fed individual ${ }^{109} \mathrm{Cd}$-labeled worms. After ingesting worms, shrimp were rinsed with distilled water, placed into gamma counting tubes containing seawater (5 ppt), and assayed for radioactivity. Shrimp were then transferred to holding chambers where they were allowed to feed ad libitum on squid tissue (Fig. 2)
(Wallace 1992). Holding chambers were maintained in a glass aquarium containing 401 $\left(5 \mathrm{ppt}, 20\right.$ to $23^{\circ} \mathrm{C}$ ) seawater. Aquarium water was continuously aerated and filtered through an aquarium filter containing activated carbon and filter media. Over the next 3 d shrimp were periodically assayed for radioactivity. The amount of egested ${ }^{109} \mathrm{Cd}$ $\left({ }^{109} \mathrm{Cd}\right.$ in fecal material) was determined by filtering the contents of the fecal collector onto a GF/C glass fiber filter and assaying the filter for radioactivity. Shrimp and fecal strands were monitored until there were no further changes in ${ }^{109} \mathrm{Cd}$ retention or egestion (i.e. after complete egestion of the radiolabeled meal).

Feeding experiment with homogenized worms (Expt 2). To determine whether the method developed for feeding shrimp separate oligochaete subcellular fractions (i.e. embedding the subcellular fractions in gelatin) altered ${ }^{109} \mathrm{Cd}$ bioavailability to shrimp the following experiment was conducted. Sixteen ${ }^{109} \mathrm{Cd}$-labeled worms (total wet wt $22 \mathrm{mg}$ ) were homogenized with a glass tissue homogenizer in $0.04 \mathrm{ml}$ distilled water. After homogenization $0.2 \mathrm{ml} \mathrm{Knox}{ }^{2}$ gelatin solution was added to the homogenate (Wallace 1992). This homogenate/gelatin slurry

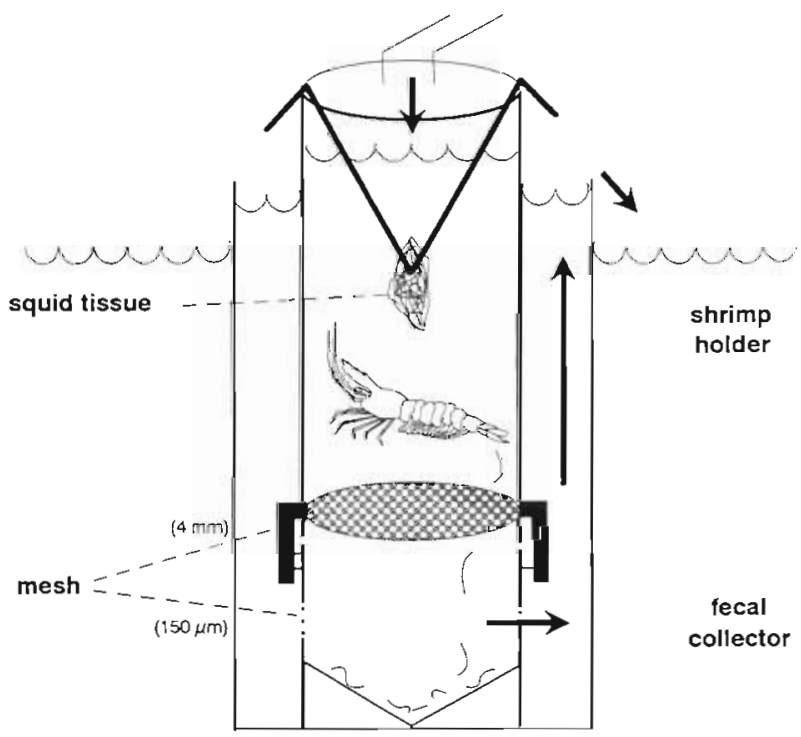

Fig. 2. Holding chambers for monitoring the retention and egestion of ${ }^{104} \mathrm{Cd}$ for shrimp fed ${ }^{10: 1} \mathrm{Cd}$-labeled meals. Chambers consisted of a polypropylene cylinder $(9 \times 2.5 \mathrm{~cm})$ with a mesh bottom that allowed fecal strands to fall into a fecal collector positioned under the mesh. A continuous flow of water washed fecal strands into fecal collectors and flushed chambers of dissolved waste. Arrows indicate the path of water Fecal collectors could be detached from the shrimp holder facilitating the removal of fecal strands 
was then homogenized by vortexing. Aliquots $(7 \mu l)$ of this gelatin were pipetted onto pre-chilled $\left(-20^{\circ} \mathrm{C}\right)$ $0.2 \mu \mathrm{m}$ membrane filters and stored frozen $\left(20^{\circ} \mathrm{C}\right.$ ) (Wallace 1992) The 'gelatin discs' on these filters were scraped off with a scalpel and were fed to shrimp. Shrimp were prepared and treated as in Expt 1.

Subcellular fractionation. To obtain subcellular fractions for use in feeding experiments, fifteen ${ }^{109} \mathrm{Cd}$ labeled worms (total wet wt $55 \mathrm{mg}$ ) were homogenized in a glass tissue homogenizer with $0.05 \mathrm{ml}$ distilled water. The homogenate was then subjected to differential centrifugation (Nash et al. 1981, Klerks 1987) (Fig. 3). Centrifugation produced a debris fraction

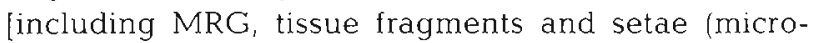
scopic observation)], an intracellular fraction (including nuclear, mitochondrial and microsomal fractions) and a cytosolic fraction (including MT and other proteins). The radioactivity of these fractions was determined and samples were stored frozen $\left(-20^{\circ} \mathrm{C}\right)$ for use in feeding experiments

Feeding experiments with subcellular fractions (Expts 3-5). The purpose of these experiments was to determine the bioavailability to shrimp of ${ }^{109} \mathrm{Cd}$ sequestered within the oligochaete debris (Expt 3), intracellular (Expt 4) and cytosolic (Expt 5) fractions. Feeding experiments were conducted by thawing the specific subcellular fraction and adding $0.19 \mathrm{ml}$ gelatin solution. Gelatin discs were then prepared and fed to shrimp as in Expt 2.

Absorption efficiency and mass balance calculations. Absorption efficiency (AE) was calculated from initial and final whole body counts:

$$
\mathrm{AE}=\left(S_{\mathrm{fin}} / S_{\mathrm{int}}\right) \times 100
$$

where $S_{\text {int }}$ is the initial ${ }^{109} \mathrm{Cd}$ radioactivity in shrimp after ingestion of the meal and $S_{\text {fin }}$ is the final ${ }^{109} \mathrm{Cd}$ radioactivity remaining in shrimp after cessation of radiolabeled feces production $(t=\sim 50 \mathrm{~h}$ ). The trophic

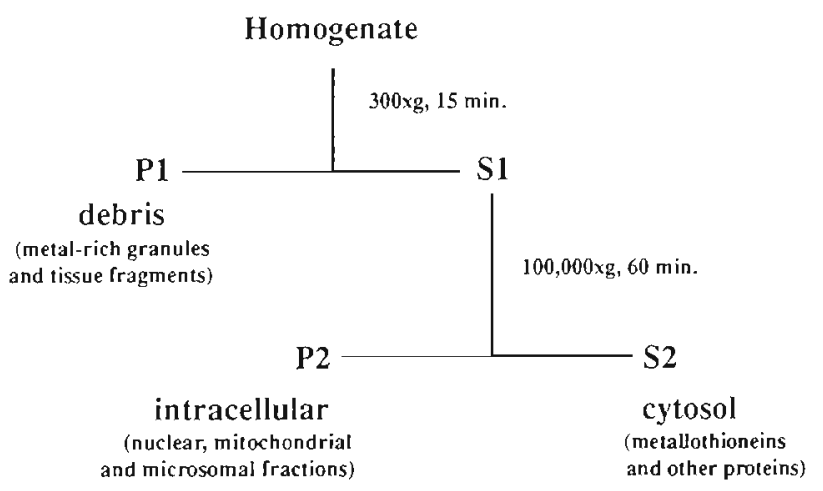

Fig. 3. Protocol for isolating subcellular fractions from ${ }^{109} \mathrm{Cd}$ labeled Limnodrilus hoffmeisteri. Subcellular fractions were used in subsequent feeding experiments transfer of ${ }^{109} \mathrm{Cd}$ was estimated by the following mass balance equation:

$$
\mathrm{AE}_{\mathrm{w}}=D \times \mathrm{AE}_{\mathrm{d}}+I \times A E_{\mathrm{l}}+C \times \mathrm{AE}_{\mathrm{c}}
$$

where $\mathrm{AE}_{w}$ is the $\mathrm{AE}$ of ${ }^{109} \mathrm{Cd}$ for shrimp fed a hypothetical whole worm; $D, I$ and $C$ represent percentages of ${ }^{109} \mathrm{Cd}$ in the oligochaete subcellular fractions (debris, intracellular and cytosol); and $\mathrm{AE}_{\mathrm{d}}, \mathrm{AE}_{1}$ and $\mathrm{AE}_{\mathrm{c}}$ are the AEs of ${ }^{109} \mathrm{Cd}$ for shrimp fed the respective subcellular fractions.

\section{RESULTS}

\section{Feeding experiments with whole and homogenized worms (Expts 1 and 2)}

The loss of ${ }^{109} \mathrm{Cd}$ from shrimp fed single whole worms (Expt 1) consisted of 2 cumponents: a rapidly exchanging pool due to the production of ${ }^{109} \mathrm{Cd}$ labeled feces and a slowly exchanging pool possibly due to physiological depuration (Fig. 4a). The AE for shrimn fed whole ${ }^{109} \mathrm{Cd}$-labcled wormis was $57.1 \%$ $( \pm 5.6 ; n=10)($ mean $\pm S E ; n$ : sample size) and the coefficient of variation (CV) of AE was $30.9 \%$. Average radioactivity in oligochaetes fed to shrimp was $48.6 \mathrm{~Bq}$ ind $^{-1}( \pm 10.2 ; n=10)$; $C V$ was $66.8 \%$.

The loss of ${ }^{109} \mathrm{Cd}$ from shrimp fed homogenized worms (Expt 2) was similar to the loss in Expt 1, except that the production of ${ }^{109} \mathrm{Cd}$-labeled feces lasted for $\sim 24 \mathrm{~h}$ (Fig. 4b). These shrimp absorbed $48.3 \%( \pm 1.7$; $\mathrm{n}=10$ ) of the ingested ${ }^{109} \mathrm{Cd}$ and the $\mathrm{CV}$ of the $\mathrm{AE}$ was $11.4 \%$. The AEs (arcsine transformed data) from Expts 1 and 2 were not significantly different $(p>0.05$; Student's $t$-test for samples with unequal variances), but there was a significant difference $(\mathrm{p}<0.05)$ between the variances (Sokal \& Rohlf 1981). These results indicated that embedding homogenized worms in gelatin did not alter ${ }^{199} \mathrm{Cd}$ bioavailability to shrimp. This method could therefore be used in feeding experiments with subcellular fractions. An additional benefit of embedding homogenized worms in gelatin is that shrimp received uniform meals. This can be seen in the extremely low $\mathrm{CV}$ of $3.4 \%$ in the radioactivity of gelatin discs fed to shrimp; the mean was $13.7 \mathrm{~Bq}$ ind. ${ }^{-1}( \pm 0.1 ; \mathrm{n}=10)$.

\section{Subcellular fractionation}

The cytosol (containing MT-like and other proteins) accounted for the largest proportion $(42.3 \%)$ of ${ }^{109} \mathrm{Cd}$ in Limnodrilus hoffmeisteri. The debris fraction, which included MRG and tissue fragments, was the second largest pool and accounted for $39.3 \%$ of the body bur- 

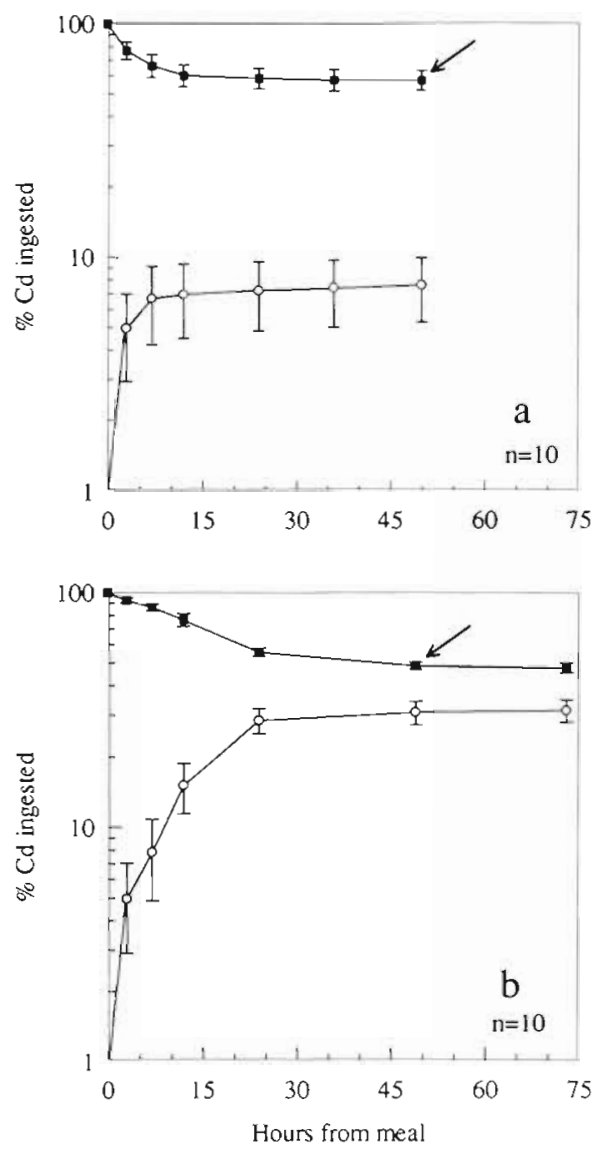

Fig. 4. (a) Retention ( - ) and egestion (o) (mean \pm SE; n: sample size) of ${ }^{109} \mathrm{Cd}$ for shrimp fed whole oligochaetes (Expt 1); or (b) homogenized oligochaetes mixed with gelatin (Expt 2). Arrows indicate times at which absorption efficiencies were calculated

den of ${ }^{109} \mathrm{Cd}$. The intracellular fraction had a minor role in Cd storage, containing only $9.3 \%$ of the ${ }^{109} \mathrm{Cd}$ in $L$. hoffmeisteri. The recovery of subcellular ${ }^{109} \mathrm{Cd}$ was high $(90.9 \%)$; minor losses occurred during transfers to centrifuge tubes.

\section{Feeding experiments with subcellular fractions (Expts 3-5)}

The AE for shrimp fed the debris fraction (Expt 3) was $48.6 \%( \pm 3.1 ; n=10)$ (Fig. 5). Shrimp absorbed $72.8 \%( \pm 4.3 ; \mathrm{n}=11)$ of the ${ }^{109} \mathrm{Cd}$ in the intracellular fraction (Expt 4, Fig. 6). In both experiments shrimp exhibited a 2 component loss of $\mathrm{Cd}$ and had ${ }^{109} \mathrm{Cd}$ egestion curves that mirrored their ${ }^{109} \mathrm{Cd}$ retention curves. Shrimp fed the cytosolic fraction (Expt 5) absorbed $84.8 \%( \pm 2.2 ; \mathrm{n}=22)$ of the ingested ${ }^{109} \mathrm{Cd}$ and displayed a gradual loss of ${ }^{109} \mathrm{Cd}$ (Fig. 7). These shrimp never produced ${ }^{109} \mathrm{Cd}$-labeled feces. Regression analysis of the ${ }^{109} \mathrm{Cd}$ retention curve for shrimp

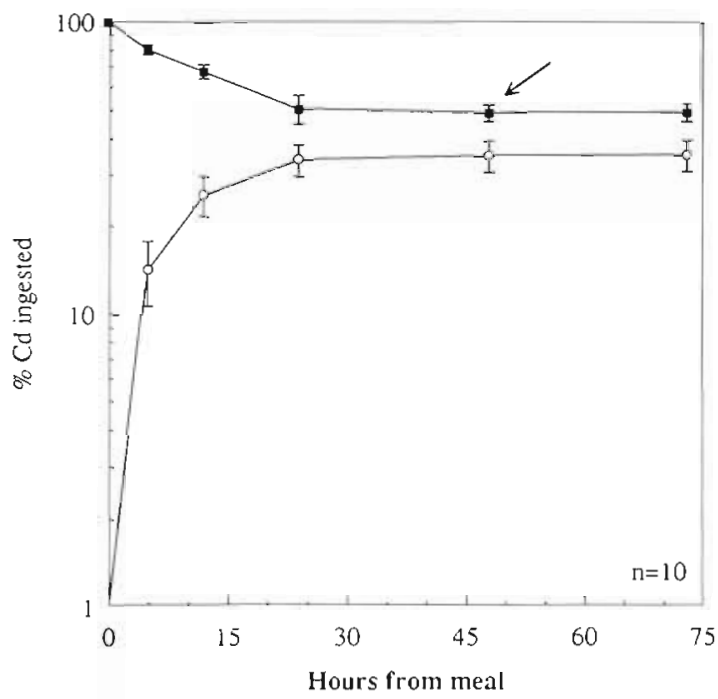

Fig. S. Retention (-) and egestion (o) (mean $\pm \mathrm{SE}$; $\mathrm{n}$ : sample size) of ${ }^{409} \mathrm{Cd}$ for shrimp fed gelatin containing a debris fraction (Expt 3) isolated from ${ }^{109} \mathrm{Cd}$-labeled oligochaetes. Arrow indicates time at which absorption efficiency was calculated

from Expt 5 yielded a $y$-intercept $(98.5 \%)$ indistinguishable from $100 \%(p>0.05)$. The ${ }^{109} \mathrm{Cd}$ loss rate or slope of this regression was $-5.5 \% \mathrm{~d}^{-1}$. Data from all subcellular fraction feeding experiments were arcsine transformed and assumptions of ANOVA were checked. The resulting ANOVA indicated a significant difference $(p<0.001)$ among AEs for shrimp fed the subcellular fractions (Expts 3-5). Multiple comparisons among pairs of means shows that shrimp fed the debris

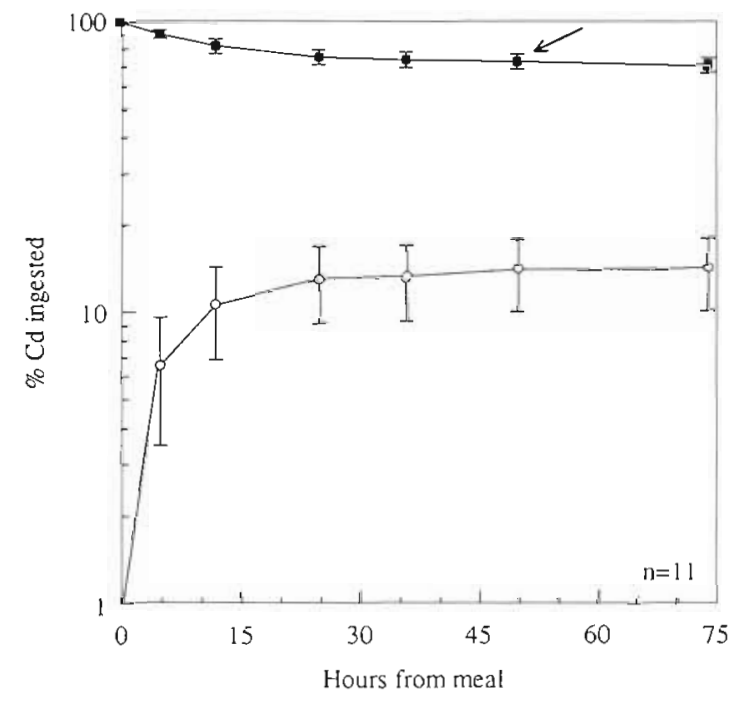

Fig. 6. Retention ( $\bullet$ ) and egestion (o) (mean $\pm \mathrm{SE}_{\text {; }}$ n: sample size) of ${ }^{109} \mathrm{Cd}$ for shrimp fed gelatin containing an intracellular fraction (Expt 4) isolated from ${ }^{109} \mathrm{Cd}$-labeled oligochaetes. Arrow indicates time at which absorption efficiency was calculated 


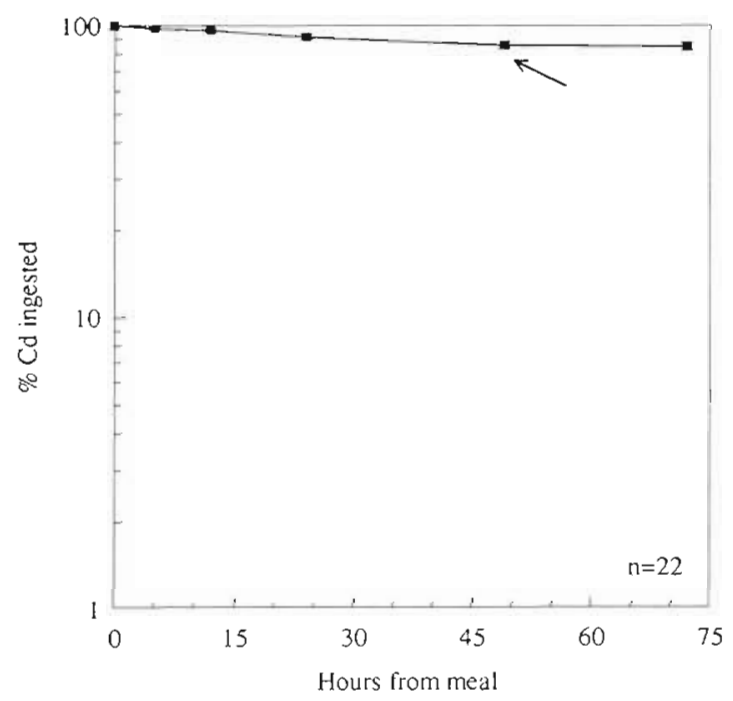

Fig. 7 Retention ( - (mean $\pm \mathrm{SE}_{\mathrm{i}}$ n: sample size) of ${ }^{109} \mathrm{Cd}$ for shrimp fed yelatin containing cytosol (Expt 5) isolated from ${ }^{109} \mathrm{Cd}$-labeled oligochaetes. Arrow indicates time at which absorption efficiency was calculated. No ${ }^{109} \mathrm{Cd}$ egestion curve is plotted because shrimp did not produce i ${ }^{109} \mathrm{Cd}$-labeled fecal strands (see 'Results')

fraction (Expt 3) absorbed significantly less ${ }^{109} \mathrm{Cd}$ ( $\mathrm{p}<$ 0.01) than did shrimp fed other subcellular fractions (Expts 4 and 5).

\section{Mass balance of $\mathrm{Cd}$ trophic transier}

Mass balance calculations indicate that Palaemonetes pugio should absorb roughly $61.5 \%$ of the ${ }^{109} \mathrm{Cd}$ in Limnodrilus hoffmeisteri, assuming that the subcellular ${ }^{109} \mathrm{Cd}$ distribution of the ingested worm corresponds to that listed in Table 1 . It is apparent from these calculations that ${ }^{109} \mathrm{Cd}$ sequestered in the cytosolic fraction, which includes MT-like proteins, constitutes the major source $(35.8 \%)$ of the ${ }^{109} \mathrm{Cd}$ absorbed by shrimp. ${ }^{109} \mathrm{Cd}$ absorbed from the debris fraction, which contains the $M R G$, is less important $(19 \%) .{ }^{109} \mathrm{Cd}$ absorbed from the intracellular fraction is minimal $(6.7 \%)$.

\section{DISCUSSION}

Limnodrilus hoffmeisteri sequesters and detoxifies $\mathrm{Cd}$ via binding to MT-like proteins and storage into MRG (Klerks \& Bartholomew 1991). Many organisms sequester essential and non-essential metals in similar fashions (Roesijadi 1980, Brown 1982). Metals stored and detoxified via the binding to MT and similar metal-binding proteins include $\mathrm{Ag}, \mathrm{Cd}, \mathrm{Cu}, \mathrm{Hg}$ and $\mathrm{Zn}$, while $\mathrm{MRG}$ have been shown to contain $\mathrm{Ag}, \mathrm{Ca}$, $\mathrm{Cd}, \mathrm{Cr}, \mathrm{Cu}, \mathrm{Fe}, \mathrm{Hg}, \mathrm{Mg}, \mathrm{Mn}, \mathrm{Ni}, \mathrm{Pb}$ and $\mathrm{Zn}$ (Roesijadi
1980, Brown 1982). If this storage and detoxification controls metal bioavailability to predators, metal detoxification at one trophic level could have ecosystem wide implications. The MT-like proteins of $L$. hoffmeisteri have an apparent molecular weight of 16000 daltons and were contained within the cytosolic fraction (Klerks \& Bartholomew 1991). Cd within this fraction was efficiently absorbed by Palaemonetes pugio. In addition to MT, L. hoffmeisteri produces 2 types of MRG: high density granules, possibly composed of $\mathrm{CdS}$, and low density granules consisting of a mixed Ca-Cd-Fe phosphate (Klerks \& Bartholomew 1991). These concretions were contained within the debris fraction, and shrimp absorbed less than half of the $\mathrm{Cd}$ contained within this fraction.

The high variance in ${ }^{109} \mathrm{Cd}$ AE for shrimp fed whole worms (Expt 1) could have been due to variability either among shrimp or among worms. The latter is more likely, as the variance in AE of shrimp fed homogenized worms mixed with gelatin (Expt 2) was much lower than that of shrimp fed whole worms. The variability in ${ }^{109} \mathrm{Cd} \mathrm{AE}$ for shrimp fed whole worms is probably controlled by differences among worms in the partitioning of ${ }^{109} \mathrm{Cd}$ among the various subcellular pools. The most important factor controlling this internal partitioning is the detoxification of Cd by MT-like proteins and MRG. Two factors that could account for differences in $\mathrm{Cd}$ detoxification among worms are genetic variability and prior Cd exposure (Klerks \& Levinton 1989b, Klerks \& Barthlomew 1991, Wallace \& Lopez 1996). These factors could have been important in this study because it was necessary to collect worms from 2 locations within the cove. Previous studies have shown that there is extreme variability in Cd tolerances among Foundry Cove worms, and sediment $\mathrm{Cd}$ concentrations in the cove are very patchy (Klerks \& Levinton 1989b).

The comparatively low $\mathrm{AE}$ of ${ }^{109} \mathrm{Cd}$ for shrimp fed the debris fraction (Expt 3) was most likely related to

Table 1. Mass balance equations for estimating ${ }^{109} \mathrm{Cd}$ absorption efficiency (AE) for shrimp fed ${ }^{109} \mathrm{Cd}$-labeled oligochaetes. Equations use a subcellular ${ }^{109} \mathrm{Cd}$ distribution obtained from ${ }^{1010} \mathrm{Cd}$-labeled oligochaetes and experimentally determined ${ }^{109} \mathrm{Cd} \mathrm{AEs}$ for shrimp fed the same subcellular fractions (Expts 3-5)

\begin{tabular}{|lrlllll|}
\hline $\begin{array}{l}\text { Subcellular } \\
\text { fraction }\end{array}$ & $\begin{array}{l}\text { \% of total } \\
\text { worm Cd }\end{array}$ & AE & & $\begin{array}{l}\% \text { Cd absorbed } \\
\text { by shrimp }\end{array}$ \\
\hline Debris & 39.3 & $\times$ & 48.6 & & 19.0 \\
Intracellular & 9.3 & $\times$ & 72.8 & $=$ & 6.7 \\
Cytosol & 42.3 & $\times$ & 84.8 & $=$ & 35.8 \\
Predicted AE for shrimp fed an & & \\
individual Cd contaminated worm & & 61.5 \\
\hline
\end{tabular}


the insolubility of MRG contained within this fraction. The gut $\mathrm{pH}$ of Palaemonetes pugio is not known, but gut pHs of similar crustaceans are between 5 and 7 (DeGuisti et al. 1962, Van Weel 1970). The Cd in the high density granules, which are presumed to be $\mathrm{CdS}$, would be biologically unavailable because CdS would not dissolve at these pHs (Gong et al. 1977). Cd in the mixed $\mathrm{Ca}-\mathrm{Cd}-\mathrm{Fe}$ phosphate granules should also be unavailable. Similar granules isolated from bivalves are insoluble in a variety of saline solutions (Simkiss 1981). Metals in some granules are bioavailable; magnesium/calcium carbonate granules in herbivorous gastropods were leached of component metals during digestion by carnivorous gastropods, but phosphate granules were relatively unaffected (Nott \& Nicolaidou 1990). Recent work has shown that $-55 \%$ of the ${ }^{109} \mathrm{Cd}$ in the debris fraction of Foundry Cove oligochaetes is in a granular fraction that is stable after being heated $\left(80^{\circ} \mathrm{C}\right)$ and exposed to $\mathrm{NaOH}_{i}$ the remaining $45 \%$ was solubilized by the procedure (Silverman et al. 1983, Wallace 1996). The percentage of ${ }^{109} \mathrm{Cd}$ solubilized from this debris fraction is in accordance with the $\mathrm{AE}$ of $48.6 \%$ for shrimp fed a similar fraction in the present study. The bioavailable ${ }^{109} \mathrm{Cd}$ in the debris fraction (Expt 3) probably came from this readily soluble fraction comprised predominantly of tissue fragments.

The ${ }^{109} \mathrm{Cd}$ in the intracellular fraction (i.e. nuclear, mitochondrial and microsomal) (Expt 4) was readily available, with an AE of $72.8 \%$. This fraction contained less than $10 \%$ of the total ${ }^{109} \mathrm{Cd}$ in the oligochaetes, which is consistent with other research demonstrating the relative unimportance of the intracellular fraction for storing Cd (Jenkins \& Mason 1988, Klerks \& Bartholomew 1991, Wallace 1992, Wallace \& Lopez 1996).

The cytosolic fraction, containing the MT-like proteins, had the highest $\mathrm{AE}(84.8 \%)$, but may have been much higher. Throughout these experiments AE was calculated by determining the percentage of ingested ${ }^{109} \mathrm{Cd}$ remaining in shrimp after the complete egestion of ${ }^{109} \mathrm{Cd}(t=\sim 50 \mathrm{~h})$. Even though shrimp fed the cytosol (Expt 5) did not produce ${ }^{109} \mathrm{Cd}$-labeled feces, AE was calculated at $t=50 \mathrm{~h}$ to be consistent with other experiments. This method for calculating AE may have underestimated AE for these shrimp. The actual AE for shrimp fed the cytosolic fraction may have been as high as $100 \%$, because metabolic depuration of ${ }^{109} \mathrm{Cd}$ is indicated by the continual gradual decline in shrimp ${ }^{109} \mathrm{Cd}$ body burden, and the $y$-intercept of the loss curve was not significantly different from $100 \%$. Calculating the $y$-intercept for a metabolic depuration curve is a more accurate method of determining $\mathrm{AE}$ (Benayoun et al. 1974). The efficient absorption of metal from cytosol has been shown for copepods and bivalve larvae fed phytoplankton and for grass shrimp fed oligochaetes (Reinfelder \& Fisher 1991, Reinfelder \& Fisher 1994, Wallace \& Lopez 1996).

Subcellular fractionation of Limnodrilus hoffmeisteri shows that both the cytosolic and debris fractions account for roughly $40 \%$ of the worms' total ${ }^{109} \mathrm{Cd}$. Mass balance calculations indicate that ${ }^{109} \mathrm{Cd}$ in the cytosol accounts for $58.2 \%$ of the ${ }^{109} \mathrm{Cd}$ absorbed by shrimp $\left(35.8 \%\right.$ of the ingested $\left.{ }^{109} \mathrm{Cd}\right)$. Furthermore, the debris fraction would account for only $30.8 \%$ of that absorbed $\left(19.0 \%\right.$ of the ingested $\left.{ }^{109} \mathrm{Cd}\right)$. The ${ }^{109} \mathrm{Cd}$ absorbed from the debris fraction probably comes from ${ }^{109} \mathrm{Cd}$ bound to tissue fragments, not MRG (Wallace 1996). The overall estimate of ${ }^{109} \mathrm{Cd} \mathrm{AE}$ is similar to that obtained for shrimp fed whole worms (Expt 1), and is slightly higher than that obtained for shrimp fed the homogenized worms mixed with gelatin (Expt 2).

\section{CONCLUSIONS}

Palaemonetes pugio fed individual Limnodrilus hoffmeisteri absorbed $57.1 \%$ of the oligochaetes' sequestered ${ }^{109} \mathrm{Cd}$. Variability in this absorption was controlled by differences among worms, most likely due to differences in subcellular distributions, rather than differences among shrimp. The subcellular ${ }^{109} \mathrm{Cd}$ distribution of oligochaetes was equally dominated by cytosol and debris. Both fractions contain the products of metal detoxification mechanisms; the former, MTlike proteins, and the latter, MRG. These divergent mechanisms for detoxifying metal play important roles in controlling metal trophic transfer. This study shows that protein-and granule-bound ${ }^{109} \mathrm{Cd}$ in $L$. hoffmeisteri were not equally available to $P$. pugio, ${ }^{109} \mathrm{Cd}$ bound to MT-like proteins was transferred with a high efficiency and ${ }^{109} \mathrm{Cd}$ bound to MRG was relatively unavailable. The ecological significance of these findings is that prey detoxification mechanisms may mediate the bioreduction or bioaccumulation of toxic metals along food chains by altering metal bioavailability. Another important finding is that the trophic transfer of metal can be predicted based on the subcellular metal distribution of prey. These concepts should be incorporated into mechanistic models that predict metal trophic transfer.

Acknowledgements. The authors thank Randall Young for his assistance in collecting oligochaetes. We thank Jeffrey Levinton, Nicholas Fisher and Steve Morgan for their valuable assistance in the laboratory and for providing comments on earlier versions of this manuscript. The comments of 3 anonymous reviewers were also very helpful. We thank the Department of Ecology and Evolution of SUNY at Stony Brook for the use of their equipment. This research was supported by The Hudson River Foundation for Science and Education. This manuscript represents contribution 1044 from the Marine Sciences Research Center, SUNY at Stony Brook. 


\section{LITERATURE CITED}

Bell SS, Coull BC (1978) Field evidence that shrimp predation regulates meiofauna. Oecologia (Berl) 35:141-1.48

Benayoun G, Fowler SW, Oregioni B (1974) Flux of cadmium through euphausiids. Mar Biol 27:205-212

Bonacina C, Bonomi G, Monti C (1989) Density-dependent processes in cohorts of Tubifex tubifex, with special emphasis on the control of fecundity. Hydrobiologia 180: $135-141$

Brenner I (1974) Heavy metal toxicities. Q Rev Biophys 7. $75-124$

Brown $\mathrm{BE}$ (1982) The form and function of metal-containing 'granules' in invertebrate tissues. Biol Rev Cam Philos Soc 57:621-667

Bryan GW (1979) Bioaccumulation of marine pollutants. Philos Trans R Soc Lond B Biol Sci 286:483-505

Capuzzo JM (1981) Predicting pollution effects in the marine environment. Oceanus 24(1):25-33

Coombs TL, George SG (1978) Mechanisms of immobilisation and detoxification of metal in marine organisms. In: Mclusky DS, Berry AJ (eds) Physiology and behavior of marine organisms. Pergamon Press, New York, p 179-187

Cousins RJ (1985) Absorption, transport and hepatic metabolism of copper and zinc: special reference to metallothionein and ceruloplasm. Physiol Rev 65:238-309

DeGiusti DL, Beigelman E, Stanley D (1962) A comparison of the pH values of the anatomiral areas of the digestive tract of the amphipods Hyalella azteca (Saussure) and Gammarus limnaeus (Smith). Trans Am Microsc Soc 81: $262-264$

George SG (1982) Subcellular accumulation and detoxification of metals in aquatic animals. In: Vernberg WB, Calabresa A. Thurnberg FP, Vernberg FJ (eds) Physiological mechanisms of marine pollutant toxicity. Academic Press, New York, p 3-55

Gong H, Rose AW, Suhr NH (1977) The geochemistry of cadmium in some sedimentary rocks. Geochim Cosmochim Acta $41: 1687-1692$

Hamer DH (1986) Metallothionein. Annu Rev Biochem 55: 913-951

Hazen RE, Kneip TJ (1980) Biogeochemical cycling of cadmium in a marsh ecosystem. In: Nriagu JO (ed) Cadmium in the environment. Part I: Ecological cycling. John Wiley and Sons, New York, p 399-424

Hoffman CP Jr (1980) Growth and reproduction of Palaemonetes pugio Holthius, and P. vulgaris (Say) populatıons in Canary Creek Marsh. Delaware. MSc thesis, University of Delaware, Newark

Huheey JE (1983) Inorganic chemisry, 3rd edn. Harper International, Cambridge

Hutcheson M, Miller DC, White AQ (1985) Respiration and behavioral responses of the grass shrimp Palaemonetes pugio to cadmium and reduced dissolved oxygen. Mar Biol 88:59-66

Jenkins KD, Mason AZ (1988) Relationships between subcellular distributions of cadmium and perturbations in reproduction in the polychaete Neanthes arenaceodentata. Aquat Toxicol 12:229-244

Kagi JHR, Kojima Y (1987) Chemistry and biochemistry of metallothionein. In: Kagi JHR, Kojima Y (eds) Metallothionein II. Birkhauser Verlag, Basel, p 25-61

Kagi JHR, Vallee BL (1961) Metallothionein: a cadmium-and zinc-containing protein from equine cortex. II. Physicochemical properties. J Biol Chem 236:2435

Klerks PL (1987) Adaptation to metals in benthic macrofauna PhD dissertation, State University of New York, Stony Brook
Klerks PL, Bartholomew PR (1991) Cadmium accumulation and detoxification in a Cd-resistant population of the oligochaete Limnodrilus hoffmeisteri. Aquat Toxicol 19 97-112

Klerks PL, Levinton JS (1989a) Effects of heavy metals in a polluted aquatic ecosystem. In: Levin SA, Harell MA. Kelly JR, Kimball KD (eds) Ecotoxicology: problems and approaches. Springer, New York, p 41-67

Klerks PL, Levinton JS (1989b) Rapid evolution of metal resistance in a benthic oligochaete inhabiting a metal-polluted site. Biol Bull (Woods Hole) 176:135-141

Kneip TJ, Hazen RE (1979) Deposit and mobility of cadmium in a march-cove ecosytem and the relation to cadmium concentration in biota. Environ Health Perspect 28:67-73

Knutson AB, Klerks PL, Levinton JS (1987) The fate of metalcontaminated sediments in Foundry Cove, New York. Environ Pollut 45: 291-304

Luoma SN (1989) Can we determine the biological availability of sediment-bound trace elements? Hydrobiologia 176/ $177: 379-396$

Nash WW, Poor BW, Jenkins KD (1981) The uptake and subcellular distribution of lead in developing sea urchin embryos. Cump Biochem Physiol 69C:205-211

Niebohr E, Richardson DHS (1980) The replacement of the nondescript term 'heavy metals' by a biologically and chemically significant classification of metal ions. Environ Pollut Ser B Chem Phys 1:3-26

Nimmo DWR, Liğhine DV', Bdiner Liti iGfF) Effects of cadmium on the shrimps, Penaeus duorarum, Palaemonetes pugio and Palaemonetes vulgaris. In: Vernberg FJ, Calabrese A, Thurberg FP, Vernberg WB (eds) Physiological response of marine biota to pollutants. Academic Press, New York, p 131-183

Nixon SW, Oviatt CA (1973) Ecology of a New England salt marsh. Ecol Monogr 43:463-498

Nomizama K (1980) Recent progress and perspectives in cadmium health effects studies. Sci Total Environ 14:199-232

Nott JA, Nicolaidou A (1.989) Metals in gastropods Metabolism and bioreduction. Mar Environ Res 28:201-205

Nott JA, Nicolaidou A (1990) Transfer of metal detoxification along marine food chains. J Mar Biol Ass UK 70:905-912

Reinfelder JR, Fisher NS (1991) The assimilation of elements ingested by marine copepods. Science 251:794-796

Reinfelder JR, Fisher NS (1994) The assimilation of elements ingested by marine planktonic bivalve larvae. Limnol Oceanogr 39(1):12-20

Roesijadi G (1980) The significance of low molecular weight, metallothionein-like proteins in marine invertebrates: current status. Mar Environ Res 4:167-179

Sadiq $M$ (1992) Cadmium in marine environments. In: Sadiq $M$ (ed) Toxic metal chemistry in marine environments. Marcel Dekker, Inc, New York, p 106-1.53

Silverman H, Steffens WL, Dietz TH (1983) Calcium concretions in the gills of freshwater mussel serve as a calcium reservoir during periods of hypoxia. J Exp Biol 227:177-189

Simkiss K (1981) Calcium, pyrophosphate and cellular pollution. Trends Biochem Sci 3:111-113

Sokal RR, Rohlf FJ (1981) Biometry, 2nd edn. WH Freeman and Co, San Francisco

Sprague JB (1986) Toxicity and tissue concentrations of lead, zinc and cadmium for marine molluscs and crustaceans. International Lead and Zinc Research Organization, Inc, Research Triangle Park, NC

Sunda WG, Engel DW, Thuotte RM (1978) Effect of chemical speciation on toxicity of cadmium to grass shrimp, Palaemonetes pugio: importance of free cadmium ion. Environ Sci Technol 12:409-413 
Van Weel PB (1970) Digestion in crustacea. In: Florkin M Scheer BT (eds) Chemical zoology, Vol 5. Academic Press, New York, p 97-115

Wallace WG (1992) The trophic transfer of biologically sequestered cadmium from the oligochaete Limnodrilus hoffmeisteri to the grass shrimp Palaemonetes pugio. MSc thesis, State University of New York, Stony Brook

Wallace WG (1996) Acclimation and adaptation to pollutants: effects on metal trophic transfer PhD dissertation. State University of New York, Stony Brook

Wallace WG, Lopez GR (1996) Relationship between the subcellular distribution of $\mathrm{Cd}$ in prey and $\mathrm{Cd}$ trophic transfer

This article was submitted to the editor to a predator. Estuaries 19(4):923-930

Welsh BL (1975) The role of grass shrimp. Palaemonetes pugio, in a tidal marsh ecosystem. Ecology 56:513-530

Wood CE (1967) Physioecology of grass shrimp, Palaemonetes pugio, in the Galveston Bay estuarine system. Contrib Mar Sci $12: 54-70$

Yamagata $N$ (1973) Manifestation of cadmium poisoning in Japan and geochemical approach to environmental pollution. In: Ingerson $E$ (ed) Proceedings of the Symposium on Hydrogeochemistry and Biogeochemistry. Tokyo, September 7-9, 1970. The Clarke Company, Washington, p $330-336$

Manuscript first received: March 29, 1996

Revised version accepted: November 5, 1996 